\title{
Optimasi Formula Nanoemulsi Nifedipin Dengan Metode Self-Nanoemulsifying Drug Delivery System (SNEDDS)
}

\author{
Zalfa Hibatullah Rahadatul Aisy ${ }^{1}$, Oktavia Eka Puspita ${ }^{1 *}$, Alvan Febrian Shalas ${ }^{1}$
}

${ }^{1}$ Jurusan Farmasi. Fakultas Kedokteran, Universitas Brawijaya, Malang, Indonesia

\begin{abstract}
INFO ARTIKEL
Sejarah artikel:

Penerimaan

naskah: 11 Juli

2019

Penerimaan

naskah revisi: 01

Juli 2020

Disetujui untuk

dipublikasikan: 26

Januari 2021

\section{Kata kunci :}

Nanoemulsi,

SNEDDS,

Nifedipin,

Optimasi

\author{
A B S T R A K
}

Nifedipin adalah obat golongan calcium channel blocker yang digunakan untuk terapi angina pektoris dan hipertensi. Nifedipin memiliki kelarutan dan bioavailabilitas yang rendah. Berdasarkan penggolongan Biopharmaceutical Classification System (BCS), nifedipin termasuk dalam kelas II. Salah satu cara untuk meningkatkan kelarutan nifedipin adalah membuat formulasi nanoemulsi nifedipin. Penelitian ini bertujuan untuk memperoleh nanoemulsi nifedipin yang optimal menggunakan metode Self-Nanoemulsifying Drug Delivery System (SNEDDS). Nanoemulsi nifedipin diperoleh melalui formula SNEDDS yang terdiri dari castor oil sebagai fase minyak, Croduret 50SS dan Span 80 sebagai surfaktan, dan PEG 400 sebagai sebagai kosurfaktan dengan rasio fase minyak:surfaktan:kosurfaktan sebesar 1:6:3. Hasil karakterisasi SNEDDS nifedipin yang optimal berwarna kuning, jernih, homogen, memiliki aroma khas SNEDDS, persen transmitansi 98,37 $\pm 0,49 \%$, waktu emulsifikasi dalam akuades dan dalam $\mathrm{HCl} 0,1 \mathrm{~N}$ berturut-turut 14,09 \pm 1,05 detik dan 11,38 \pm 0,66 detik, ukuran globul 24,05 \pm $0,02 \mathrm{~nm}$, indeks polidispersitas $0,277 \pm 0,0038, \mathrm{pH} 6,95$, loading dose capacity $50 \mathrm{mg}$ nifedipin dalam 1 g SNEDDS dan kadar nifedipin dalam formula SNEDDS 9,857 $\pm 0,345 \mathrm{mg} / \mathrm{g}$. Uji stabilitas termodinamika dan uji stabilitas on going menunjukkan bahwa sediaan stabil secara fisik.

\section{Optimization of Nifedipine Nanoemulsion Formula Using Self-Nanoemulsifying Drug Delivey System (SNEDDS) Method}

\section{Keywords:}

Nanoemulsion, SNEDDS,

Nifedipine, Optimization

\section{A B S T R A C T}

Nifedipine is a calcium channel blocker used for angina and hypertension therapy. Nifedipine has low solubility in water thus low bioavailability. Nifedipine is classified as Biopharmaceutical Classification System (BCS) class II. Nanoemulsion can be made to enhance the solubility of nifedipine. The objective of this study is to obtain optimum formula of nifedipine nanoemulsion by using SelfNanoemulsifying Drug Delivey System (SNEDDS) method. Nifedipine nanoemulsion was made of castor oil as oil phase, Croduret 50SS and Span 80 as surfactant, and PEG 400 as co-surfactant. The optimum formula had ratio of oil:surfactant:co-surfactant 1:6:3. The optimum formula was homogenous, clear, yellow, and viscous. The percentage of transmittance was 98,37 $\pm 0,49 \%$. The emulsification time in water and $\mathrm{HCl} 0,1 \mathrm{~N}$ were 14,09 $\pm 1,05 \mathrm{~s}$ dan 11,38 $\pm 0,66 \mathrm{~s}$, consecutively. The droplet size was $24,05 \pm 0,02 \mathrm{~nm}$ and the polidispersity index was $0,277 \pm 0,0038$. The $\mathrm{pH}$ was 6,95 . Nifedipine SNEDDS had loading dose capacity $50 \mathrm{mg} / \mathrm{g}$ and drug content $9,857 \pm 0,345 \mathrm{mg} / \mathrm{g}$. Thermodynamic stability test and on going stability test towards the formulation showed phisically stable formulation. 


\section{Pendahuluan}

Hipertensi dapat diartikan sebagai peningkatan tekanan darah sistolik lebih dari atau sama dengan 140 $\mathrm{mmHg}$ dan tekanan diastolik lebih dari atau sama dengan $90 \mathrm{mmHg}$. Hipertensi dapat menyebabkan berbagai komplikasi seperti infark miokard, gagal ginjal, stroke, hingga kematian. ${ }^{1,2}$ Obat-obatan yang dapat dipilih sebagai lini pertama untuk hipertensi antara lain angiotensinconverting enzyme (ACE) inhibitors, angiotensin II receptor blockers (ARB), calcium channel blockers (CCB), dan diuretik thiazid. ${ }^{3}$

Nifedipin merupakan obat golongan calcium channel blockers jenis dihidropiridin yang digunakan untuk terapi angina pektoris dan hipertensi. Nifedipin bekerja dengan menghambat ion kalsium masuk ke membran sel otot jantung dan otot polos pembuluh darah selama depolarisasi sehingga akan menurunkan resistensi perifer dan menurunkan tekanan darah. Nifedipin diberikan melalui rute oral dengan dosis $10 \mathrm{mg}$ hingga $40 \mathrm{mg}$ dua kali sehari, atau $20 \mathrm{mg}$ hingga $90 \mathrm{mg}$ satu kali sehari. Nifedipin diabsorbsi secara cepat pada saluran cerna, namun mengalami metabolisme lintas pertama. Bioavailabilitas kapsul nifedipin yang diberikan secara oral adalah 45 hingga $75 \% .^{4}$

Nifedipin bersifat lipofil dan memiliki kelarutan yang rendah. Kelarutan nifedipin sebesar 1:10.000 atau praktis tidak larut dalam air dan sebesar 1:10 atau mudah larut dalam aseton. Berdasarkan Biopharmaceutical Classification System, nifedipin termasuk kelas II, yang memiliki karakteristik kelarutan rendah dan permeabilitas tinggi. ${ }^{5}$ Kelarutan rendah dapat menyebabkan disolusi menjadi lebih lambat. Bioavailabilitas oral dari nifedipin juga termasuk rendah akibat dipengaruhi oleh metabolisme lintas pertama. ${ }^{6}$ Oleh karena itu, bioavailabilitas senyawa yang memiliki kelarutan dalam air rendah seperti nifedipin bergantung pada formulasi untuk meningkatkan kelarutan dan mencegah metabolisme lintas pertama dari obat.

Formulasi berbasis lipid merupakan salah satu cara yang dapat dipilih untuk memodifikasi sistem penghantaran obat BCS kelas II. Formulasi berbasis lipid dapat meningkatkan absorpsi obat dengan meningkatkan kelarutan dan menstimulasi transpor obat melalui jalur limfatik. ${ }^{7}$ Nanoemulsi merupakan formulasi berbasis lipid yang dipilih untuk penelitian ini. Nanoemulsi adalah dispersi koloid dari dua cairan yang tidak bercampur yang memiliki ukuran globul 20-200 nm. Ukuran droplet yang kecil dan kemampuan nanoemulsi untuk melarutkan obat yang tidak larut dalam air bermanfaat untuk meningkatkan kecepatan disolusi obat dan meningkatkan bioavailabilitas sistemik. $^{8-9}$

Saat ini telah banyak dikembangkan pembuatan nanoemulsi menggunakan energi rendah yang memanfaatkan energi internal dalam sistem untuk membantu pembentukan nanoemulsi. Salah satu metode untuk membuat nanoemulsi dengan energi rendah yaitu Self-Nanoemulsifying Drug Delivery System (SNEDDS). SNEDDS merupakan campuran isotropik dari minyak, surfaktan, serta satu atau lebih kosolven hidrofilik atau kosurfaktan yang akan membentuk nanoemulsi minyak dalam air saat didispersikan media aqueous dengan pengadukan ringan. ${ }^{10}$ Komponen minyak dalam SNEDDS dapat membantu disolusi obat yang tidak larut air serta dapat meningkatkan disolusi obat dalam usus sehingga obat akan masuk ke jalur limfatik. Transpor obat melewati sistem limfatik dapat mencegah obat mengalami metabolisme lintas pertama sehingga akan meningatkan bioavailabilitas obat. ${ }^{7}$ SNEDDS dapat meningkatkan stabilitas fisik maupun kimiawi dari sediaan pada penyimpanan jangka panjang. Pembuatan SNEDDS juga memungkinkan formulasi lebih lanjut menjadi bentuk sediaan dosis terbagi, seperti kapsul gelatin atau hidroksipropil metilselulosa keras maupun lunak, sehingga dapat meningkatkan kenyamanan pasien dalam meminum obat dan tidak menimbulkan rasa yang tidak enak. ${ }^{11}$

Oleh karena itu, pada penelitian ini dilakukan optimasi formula nanoemulsi nifedipin dengan metode SNEDDS menggunakan beberapa rasio minyak:Smix. Formula SNEDDS dibuat menggunakan castor oil sebagai fase minyak, Tween 80/Span 20 dan Croduret 50SS/Span 80 sebagai surfaktan, dan PEG 400 sebagai kosurfaktan. Tujuan dari penelitian ini adalah untuk mendapatkan hasil perbandingan fase minyak, surfaktan, dan kosurfaktan yang dapat membentuk SNEDDS nifedipin dengan karakteristik fisik yang optimal, meliputi organoleptik, persen transmitansi, waktu emulsifikasi, dan ukuran globul, serta untuk mengetahui stabilitas fisik formula optimal SNEDDS nifedipin.

\section{Metode}

Bahan

Bahan-bahan yang digunakan untuk membuat nanoemulsi nifedipin adalah Nifedipin (PT Kimia Farma Tbk, Plant Bandung), Tween 80 (Duta Jaya Lab Ware), Span 20 (Duta Jaya Lab Ware), Croduret 50 SS (Croda), Span 80, PEG 400 (Duta Jaya Lab Ware), castor oil (Duta Jaya Lab Ware), dan akuades.

\section{Alat}

Alat yang digunakan dalam pembuatan dan evaluasi nanoemulsi nifedipin adalah baker glass (PYREX, IWAKI, HERMA), gelas ukur (PYREX), pipet volume (IWAKI), pipet tetes, magnetic stirrer (IKA C-MAG HS 4), dan mikropipet (SOCOREX), timbangan digital (OHAUS PIONEER ${ }^{\mathrm{TM}}$ ), spektrofotometer UV-Vis (SHIMADZU UV-1800), Zetasizer (Malvern Zetasizer Nano Series), kulkas (LG), oven (BINDER), vortex (Genie Mixer), sentrifuse (Bench Nuve NF 400 R), freezer (RSA), pH meter (TOA).

\section{Optimasi Formula SNEDDS}

\section{1) Screening Rasio Fase Minyak : Smix}

Screening rasio fase minyak:Smix dilakukan untuk mencari formula SNEDDS yang prospektif. Minyak dan campuran surfaktan dengan kosurfaktan (Smix) dikelompokkan pada berbagai perbandingan massa $\left(\mathrm{Smix}_{1}, \mathrm{Smix}_{2}, \mathrm{Smix}_{3}, \mathrm{Smix}_{4}\right.$, $\mathrm{Smix}_{5}, \mathrm{Smix}_{6}, \mathrm{Smix}_{7}$, dan $\mathrm{Smix}_{8}$ ). Komposisi kombinasi surfaktan dalam Smix diperoleh melalui perhitungan HLB. 
HLB yang digunakan adalah HLB butuh castor oil yaitu 14. Tiap Smix dicampur dengan castor oil pada berbagai rasio $(1: 9,2: 8,3: 7,4: 6,5: 5,6: 4,7: 3,8: 2$, dan 9:1). Formula SNEDDS dapat dilihat pada tabel 1 hingga 8. Campuran minyak dan Smix diambil sebanyak $5 \mu \mathrm{L}$ dan didispersikan dalam $5 \mathrm{ml}$ akuades. Kemudian dilakukan karakterisasi uji persen transmitansi dan waktu emulsifikasi. Persyaratan formula prospektif yaitu karakteristik organoleptik kuning, jernih, homogen, berbau khas SNEDDS; persen transmitansi 90-100\%; dan waktu emulsifikasi $<60$ detik.

Tabel 1. Optimasi Formula Smix

\begin{tabular}{|c|c|c|c|c|}
\hline \multirow{3}{*}{$\begin{array}{l}\text { Fase minyak : } \\
\qquad \text { Smix }\end{array}$} & \multirow{3}{*}{$\begin{array}{c}\text { Castor } \\
\text { oil } \\
\text { (g) }\end{array}$} & \multicolumn{3}{|c|}{ Smix $_{1}$} \\
\hline & & \multicolumn{2}{|c|}{$\begin{array}{l}\text { Tween } 80 \text { : Span } 20 \\
84,375 \%: 15,625 \%\end{array}$} & \multirow{2}{*}{$\begin{array}{c}\text { PEG } \\
400 \\
(\mathrm{~g})\end{array}$} \\
\hline & & $\begin{array}{c}\text { Tween } 80 \\
\text { (g) } \\
\end{array}$ & $\begin{array}{c}\text { Span } 20 \\
(\mathrm{~g})\end{array}$ & \\
\hline $1: 9$ & 0,500 & 1,898 & 0,352 & 2,250 \\
\hline $2: 8$ & 1,000 & 1,688 & 0,313 & 2,000 \\
\hline $3: 7$ & 1,500 & 1,477 & 0,273 & 1,750 \\
\hline $4: 6$ & 2,000 & 1,266 & 0,234 & 1,500 \\
\hline $5: 5$ & 2,500 & 1,055 & 0,195 & 1,250 \\
\hline $6: 4$ & 3,000 & 0,844 & 0,156 & 1,000 \\
\hline $7: 3$ & 3,500 & 0,633 & 0,117 & 0,750 \\
\hline $8: 2$ & 4,000 & 0,422 & 0,078 & 0,500 \\
\hline $9: 1$ & 4,500 & 0,211 & 0,039 & 0,250 \\
\hline
\end{tabular}

Keterangan: Smix $_{1}$ adalah rasio Tween 80/Span 20 : PEG 400 = 1:1

Tabel 2. Optimasi Formula Smix ${ }_{2}$

\begin{tabular}{ccccc} 
& & \multicolumn{3}{c}{ Smix $_{2}$} \\
\cline { 3 - 4 } Fase minyak : & $\begin{array}{c}\text { Castor } \\
\text { Smix }\end{array}$ & $\begin{array}{c}\text { oil } \\
(\mathbf{g})\end{array}$ & $\begin{array}{c}\text { Tween 80 : Span 20 } \\
\mathbf{8 4 , 3 7 5 \%}: \mathbf{1 5 , 6 2 5 \%}\end{array}$ & PEG \\
& & $\begin{array}{c}\text { Tween 80 } \\
(\mathbf{g})\end{array}$ & $\begin{array}{c}\text { Span 20 } \\
(\mathbf{g})\end{array}$ & $\begin{array}{c}\mathbf{4 0 0} \\
(\mathbf{g})\end{array}$ \\
\hline & & 2,531 & 0,469 & 1,500 \\
\hline $1: 9$ & 0,500 & 2,250 & 0,417 & 1,333 \\
\hline $2: 8$ & 1,000 & 1,969 & 0,365 & 1,167 \\
\hline $3: 7$ & 1,500 & 1,688 & 0,313 & 1,000 \\
\hline $4: 6$ & 2,000 & 1,406 & 0,260 & 0,833 \\
\hline $5: 5$ & 2,500 & 1,125 & 0,208 & 0,667 \\
\hline $6: 4$ & 3,000 & 0,844 & 0,156 & 0,500 \\
\hline $7: 3$ & 3,500 & 0,563 & 0,104 & 0,333 \\
\hline $8: 2$ & 4,000 & 0,281 & 0,052 & 0,167 \\
\hline $9: 1$ & 4,500 & &
\end{tabular}

Keterangan: $\mathrm{Smix}_{2}$ adalah rasio Tween 80/Span 20 : PEG $400=2: 1$

Tabel 3. Optimasi Formula $\mathrm{Smix}_{3}$

\begin{tabular}{|c|c|c|c|c|}
\hline & \multirow{4}{*}{$\begin{array}{c}\text { Castor } \\
\text { oil } \\
(\mathrm{g})\end{array}$} & last Formul & $\operatorname{mix}_{3}$ & \\
\hline \multirow{3}{*}{$\begin{array}{c}\text { Fase minyak : } \\
\text { Smix }\end{array}$} & & \multicolumn{3}{|c|}{ Smix $_{3}$} \\
\hline & & \multicolumn{2}{|c|}{$\begin{array}{l}\text { Tween } 80 \text { : Span } 20 \\
84,375 \%: 15,625 \%\end{array}$} & \multirow{2}{*}{$\begin{array}{c}\text { PEG } \\
400 \\
(g)\end{array}$} \\
\hline & & $\begin{array}{c}\text { Tween } 80 \\
\text { (g) }\end{array}$ & $\begin{array}{c}\text { Span } 20 \\
\text { (g) }\end{array}$ & \\
\hline $1: 9$ & 0,500 & 2,848 & 0,527 & 1,125 \\
\hline $2: 8$ & 1,000 & 2,531 & 0,469 & 1,000 \\
\hline $3: 7$ & 1,500 & 2,215 & 0,410 & 0,875 \\
\hline $4: 6$ & 2,000 & 1,898 & 0,352 & 0,750 \\
\hline $5: 5$ & 2,500 & 1,582 & 0,293 & 0,625 \\
\hline $6: 4$ & 3,000 & 1,266 & 0,234 & 0,500 \\
\hline
\end{tabular}

\begin{tabular}{ccccc}
\hline $7: 3$ & 3,500 & 0,949 & 0,176 & 0,375 \\
\hline $8: 2$ & 4,000 & 0,633 & 0,117 & 0,250 \\
\hline $9: 1$ & 4,500 & 0,316 & 0,059 & 0,125 \\
\hline
\end{tabular}

Keterangan: $\mathrm{Smix}_{3}$ adalah rasio Tween $80 / \mathrm{Span} 20$ :

PEG 400 $=3: 1$

Tabel 4. Optimasi Formula $\mathrm{Smix}_{4}$

\begin{tabular}{|c|c|c|c|c|}
\hline \multirow{3}{*}{$\begin{array}{l}\text { Fase minyak } \\
\quad: \text { Smix }\end{array}$} & \multirow{3}{*}{$\begin{array}{c}\text { Castor } \\
\text { oil } \\
\text { (g) }\end{array}$} & \multicolumn{3}{|c|}{ Smix $_{4}$} \\
\hline & & \multicolumn{2}{|c|}{$\begin{array}{l}\text { Tween } 80 \text { : Span } 20 \\
84,375 \%: 15,625 \%\end{array}$} & \multirow{2}{*}{$\begin{array}{c}\text { PEG } \\
\text { 400 } \\
(\mathrm{g})\end{array}$} \\
\hline & & $\begin{array}{c}\text { Tween } 80 \\
\text { (g) }\end{array}$ & $\begin{array}{c}\text { Span } 20 \\
\text { (g) }\end{array}$ & \\
\hline $1: 9$ & 0,500 & 3,038 & 0,563 & 0,900 \\
\hline $2: 8$ & 1,000 & 2,700 & 0,500 & 0,800 \\
\hline $3: 7$ & 1,500 & 2,363 & 0,438 & 0,700 \\
\hline $4: 6$ & 2,000 & 2,025 & 0,375 & 0,600 \\
\hline $5: 5$ & 2,500 & 1,688 & 0,313 & 0,500 \\
\hline $6: 4$ & 3,000 & 1,350 & 0,250 & 0,400 \\
\hline $7: 3$ & 3,500 & 1,013 & 0,188 & 0,300 \\
\hline $8: 2$ & 4,000 & 0,675 & 0,125 & 0,200 \\
\hline $9: 1$ & 4,500 & 0,338 & 0,063 & 0,100 \\
\hline
\end{tabular}

Keterangan: $\mathrm{Smix}_{4}$ adalah rasio Tween $80 / \mathrm{Span} 20$ : PEG $400=4: 1$

Tabel 5. Optimasi Formula Smix

\begin{tabular}{|c|c|c|c|c|}
\hline \multirow{3}{*}{$\begin{array}{l}\text { Fase minyak : } \\
\qquad \text { Smix }\end{array}$} & \multirow{3}{*}{$\begin{array}{c}\text { Castor } \\
\text { oil } \\
(\mathrm{g})\end{array}$} & \multicolumn{3}{|c|}{ Smix $_{5}$} \\
\hline & & \multicolumn{2}{|c|}{$\begin{array}{c}\text { Croduret 50SS : Span } 80 \\
98,979 \%: 1,021 \%\end{array}$} & \multirow{2}{*}{$\begin{array}{c}\text { PEG } \\
400 \\
(\mathrm{~g})\end{array}$} \\
\hline & & $\begin{array}{c}\text { Croduret } \\
50 S S(g)\end{array}$ & $\begin{array}{c}\text { Span } 80 \\
\text { (g) }\end{array}$ & \\
\hline $1: 9$ & 0,300 & 1,336 & 0,014 & 1,350 \\
\hline $2: 8$ & 0,600 & 1,188 & 0,012 & 1,200 \\
\hline $3: 7$ & 0,900 & 1,039 & 0,011 & 1,050 \\
\hline $4: 6$ & 1,200 & 0,891 & 0,009 & 0,900 \\
\hline $5: 5$ & 1,500 & 0,742 & 0,008 & 0,750 \\
\hline $6: 4$ & 1,800 & 0,594 & 0,006 & 0,600 \\
\hline $7: 3$ & 2,100 & 0,445 & 0,005 & 0,450 \\
\hline $8: 2$ & 2,400 & 0,297 & 0,003 & 0,300 \\
\hline $9: 1$ & 2,700 & 0,149 & 0,002 & 0,150 \\
\hline
\end{tabular}

Keterangan: Smix 5 adalah rasio Croduret 50SS/Span 80 : PEG 400 =1:1

Tabel 6. Optimasi Formula Smix 6

\begin{tabular}{|c|c|c|c|c|}
\hline \multirow{3}{*}{$\begin{array}{l}\text { Fase minyak } \\
\quad \text { : Smix }\end{array}$} & \multirow{3}{*}{$\begin{array}{c}\text { Castor } \\
\text { oil } \\
(\mathrm{g})\end{array}$} & \multicolumn{3}{|c|}{ Smix $_{6}$} \\
\hline & & \multicolumn{2}{|c|}{$\begin{array}{c}\text { Croduret 50SS : Span } 80 \\
98,979 \%: 1,021 \%\end{array}$} & \multirow{2}{*}{$\begin{array}{c}\text { PEG } 400 \\
\text { (g) }\end{array}$} \\
\hline & & $\begin{array}{l}\text { Croduret } \\
\text { 50SS (g) }\end{array}$ & $\begin{array}{l}\text { Span } 80 \\
(\mathrm{~g})\end{array}$ & \\
\hline $1: 9$ & 0,300 & 1,782 & 0,018 & 0,900 \\
\hline $2: 8$ & 0,600 & 1,584 & 0,016 & 0,800 \\
\hline $3: 7$ & 0,900 & 1,386 & 0,014 & 0,700 \\
\hline $4: 6$ & 1,200 & 1,188 & 0,012 & 0,600 \\
\hline $5: 5$ & 1,500 & 0,990 & 0,010 & 0,500 \\
\hline $6: 4$ & 1,800 & 0,792 & 0,008 & 0,400 \\
\hline $7: 3$ & 2,100 & 0,594 & 0,006 & 0,300 \\
\hline $8: 2$ & 2,400 & 0,396 & 0,004 & 0,200 \\
\hline $9: 1$ & 2,700 & 0,198 & 0,002 & 0,100 \\
\hline
\end{tabular}

Keterangan: $\mathrm{Smix}_{6}$ adalah rasio Croduret 50SS/Span 80 : PEG $400=2: 1$ 
Tabel 7. Optimasi Formula $\operatorname{Smix}_{7}$

\begin{tabular}{|c|c|c|c|c|}
\hline \multirow{3}{*}{$\begin{array}{c}\text { Fase minyak : } \\
\text { Smix }\end{array}$} & \multirow{3}{*}{$\begin{array}{c}\text { Castor } \\
\text { oil } \\
(\mathrm{g})\end{array}$} & \multicolumn{3}{|c|}{ Smix $_{7}$} \\
\hline & & \multicolumn{2}{|c|}{$\begin{array}{c}\text { Croduret 50SS : Span } 80 \\
98,979 \%: 1,021 \%\end{array}$} & \multirow{2}{*}{$\begin{array}{c}\text { PEG } \\
400 \\
(\mathrm{~g})\end{array}$} \\
\hline & & $\begin{array}{l}\text { Croduret } \\
\text { 50SS (g) }\end{array}$ & $\begin{array}{l}\text { Span } 80 \\
(\mathrm{~g})\end{array}$ & \\
\hline $1: 9$ & 0,300 & 2,004 & 0,021 & 0,675 \\
\hline $2: 8$ & 0,600 & 1,782 & 0,018 & 0,600 \\
\hline $3: 7$ & 0,900 & 1,559 & 0,016 & 0,525 \\
\hline $4: 6$ & 1,200 & 1,336 & 0,014 & 0,450 \\
\hline $5: 5$ & 1,500 & 1,114 & 0,012 & 0,375 \\
\hline $6: 4$ & 1,800 & 0,891 & 0,009 & 0,300 \\
\hline $7: 3$ & 2,100 & 0,668 & 0,007 & 0,225 \\
\hline $8: 2$ & 2,400 & 0,445 & 0,005 & 0,150 \\
\hline $9: 1$ & 2,700 & 0,223 & 0,002 & 0,075 \\
\hline
\end{tabular}

Keterangan: $\mathrm{Smix}_{7}$ adalah rasio Croduret 50SS/Span $80:$ PEG $400=3: 1$

Tabel 8. Optimasi Formula Smix

\begin{tabular}{|c|c|c|c|c|}
\hline \multirow{3}{*}{$\begin{array}{l}\text { Fase minyak : } \\
\text { Smix }\end{array}$} & \multirow{3}{*}{$\begin{array}{c}\text { Castor } \\
\text { oil } \\
(\mathrm{g})\end{array}$} & \multicolumn{3}{|c|}{ Smix $_{8}$} \\
\hline & & \multicolumn{2}{|c|}{$\begin{array}{c}\text { Croduret 50SS : Span } 80 \\
98,979 \%: 1,021 \%\end{array}$} & \multirow{2}{*}{$\begin{array}{c}\text { PEG } \\
400 \\
(g)\end{array}$} \\
\hline & & $\begin{array}{c}\text { Croduret } \\
\text { 50SS (g) }\end{array}$ & $\begin{array}{c}\text { Span } 80 \\
(\mathrm{~g})\end{array}$ & \\
\hline $1: 9$ & 0,300 & 2,138 & 0,022 & 0,540 \\
\hline $2: 8$ & 0,600 & 1,900 & 0,020 & 0,480 \\
\hline $3: 7$ & 0,900 & 1,663 & 0,017 & 0,420 \\
\hline $4: 6$ & 1,200 & 1,425 & 0,015 & 0,360 \\
\hline $5: 5$ & 1,500 & 1,188 & 0,012 & 0,300 \\
\hline $6: 4$ & 1,800 & 0,950 & 0,010 & 0,240 \\
\hline $7: 3$ & 2,100 & 0,713 & 0,007 & 0,180 \\
\hline $8: 2$ & 2,400 & 0,475 & 0,005 & 0,120 \\
\hline $9: 1$ & 2,700 & 0,238 & 0,003 & 0,060 \\
\hline
\end{tabular}

\section{2) Optimasi Formula SNEDDS Nifedipin}

Formula SNEDDS dengan rasio fase minyak:Smix yang prospektif ditambahkan nifedipin. Tiap formula dikarakterisasi meliputi uji persen transmitansi, waktu emulsifikasi, dan ukuran globul. Formula yang memenuhi persyaratan persen transmitansi, waktu emulsifikasi, dan ukuran globul diuji stabilitas termodinamika. Kemudian formula yang terpilih dilanjutkan untuk uji $\mathrm{pH}$, uji drug loading capacity, dan uji penetapan kadar.

\section{Prosedur Pembuatan SNEDDS}

Fase minyak, surfaktan, dan kosurfaktan yang sudah ditimbang diaduk menggunakan magnetic stirrer pada kecepatan $500 \mathrm{rpm}$ selama 20 menit pada suhu $40^{\circ} \mathrm{C}$ hingga terbentuk campuran yang homogen. Nifedipin ditimbang sebanyak $10 \mathrm{mg}$ untuk setiap $1 \mathrm{~g}$ SNEDDS. Kemudian nifedipin ditambahkan ke dalam SNEDDS dan diaduk menggunakan magnetic stirrer pada kecepatan 500 rpm selama 90 menit pada suhu ruang hingga terbentuk campuran yang homogen. SNEDDS nifedipin disimpan pada suhu ruang dan terhindar dari cahaya untuk pengujian selanjutnya.

\section{Karakterisasi SNEDDS}

\section{1) Uji Organoleptik}

Sediaan SNEDDS diamati dengan indra dari segi warna, kejernihan, dan bau.

\section{2) Ukuran Globul}

Sebanyak $100 \mu \mathrm{l}$ SNEDDS dilarutkan dalam $10 \mathrm{ml}$ akuades dan dihomogenkan menggunakan vortex. Larutan tersebut dimasukkan ke dalam kuvet dan diukur menggunakan instrumen Zetasizer. ${ }^{12,13}$

\section{3) Indeks Polidispersitas}

Sebanyak $100 \mu \mathrm{l}$ SNEDDS dilarutkan dalam $10 \mathrm{ml}$ akuades dan dihomogenkan menggunakan vortex. Larutan tersebut dimasukkan ke dalam kuvet dan diukur menggunakan instrumen Zetasizer. ${ }^{14}$

\section{4) $\mathrm{pH}$}

Sebanyak $100 \mu \mathrm{l}$ SNEDDS dilarutkan dalam $5 \mathrm{ml}$ akuades dan diukur $\mathrm{pH}$ sediaan menggunakan $\mathrm{pH}$ meter.

\section{5) Persen Transmitansi}

Sebanyak $100 \mu \mathrm{l}$ SNEDDS ditambahkan $5 \mathrm{ml}$ akuades dan dihomogenkan menggunakan vortex selama 60 detik. Persen transmitansi diukur menggunakan spektrofotometer UV-Vis pada panjang gelombang $650 \mathrm{~nm}$ dengan blanko akuades. ${ }^{1}$

\section{6) Penetapan Kadar Nifedipin}

SNEDDS yang mengandung $10 \mathrm{mg}$ nifedipin dimasukkan ke dalam labu ukur $100 \mathrm{ml}$ kemudian ditambahkan $1 \mathrm{ml}$ kloroform dan ditambahkan metanol hingga tanda batas. Kemudian larutan SNEDDS diencerkan hingga konsentrasi 100 ppm sebagai larutan uji. ${ }^{16}$ Larutan uji dianalisis menggunakan spektrofotometer UV-Vis pada panjang gelombang 235,60 $\mathrm{nm}$. Serbuk nifedipin digunakan sebagai standar untuk menentukan panjang gelombang maksimal.

\section{7) Waktu Emulsifikasi}

Sebanyak $1 \mathrm{ml}$ SNEDDS dimasukkan sekaligus ke dalam masing-masing $250 \mathrm{ml}$ air suling dan $\mathrm{HCl} 0,1 \mathrm{~N}$ pada suhu $37 \pm 2{ }^{\circ} \mathrm{C}$ dan diaduk perlahan menggunakan magnetic stirrer pada kecepatan $100 \mathrm{rpm}$. Waktu diukur saat SNEDDS masuk ke dalam media dan dihentikan saat terbentuk nanoemulsi yang homogen. ${ }^{12}$

\section{Uji Stabilitas Termodinamika ${ }^{12}$}

\section{1) Uji Heating-Cooling Cycle}

SNEDDS disimpan pada suhu $4^{\circ} \mathrm{C}$ dan $45^{\circ} \mathrm{C}$ sebanyak 6 siklus masing-masing suhu selama 24 jam. SNEDDS diamati perubahan secara organoleptik.

\section{2) Uji Sentrifugasi}

SNEDDS yang stabil pada uji heating-cooling cycle disentrifugasi pada kecepatan $3500 \mathrm{rpm}$ selama 30 menit. SNEDDS diamati perubahan secara organoleptik.

\section{3) Uji Freeze-Thaw}

SNEDDS yang stabil pada uji sentrifugasi disimpan pada suhu suhu $-21^{\circ} \mathrm{C}$ dan $25^{\circ} \mathrm{C}$ selama tidak kurang dari 48 jam. SNEDDS yang stabil kemudian disentrifugasi selama 5 menit pada kecepatan $3000 \mathrm{rpm}$. SNEDDS diamati perubahannya (organoleptik, persen transmitansi, dan waktu emulsifikasi)

\section{Uji Stabilitas On Going}

SNEDDS disimpan pada suhu ruang selama 30 hari dan diamati perubahannya secara organoleptik.

\section{Analisis Data}

Analisis data hasilpenelitiandilakukandengan uji statistikmenggunakansoftware IBM SPSS 20.0. Data hasilpenelitiandiujinormalitasdan diujihomogenitas. Jika distribusi data normal dan varians data sama, maka analisis 
data dilakukan dengan statistic parametric menggunakan metode One Way ANOVA. Jika distribusi data tidak normal dan/atau varians data tidak sama, maka dilakukan transformasi data supaya distribusi menjadi normal dan varians menjadi sama. Jika variable baru hasil transformasi tidak berdistribusi normal atau varians data tetap tidak sama maka analisis data dilakukan dengan statistik non parametrik menggunakan metode Kruskal-Wallis sebagai alternatif.

\section{Hasil dan Diskusi}

\section{Hasil Optimasi Formula SNEDDS}

\section{1) Hasil Pengenceran Formula SNEDDS}

Optimasi formula dilakukan dengan membuat formula SNEDDS pada berbagai rasio kemudian diuji dengan cara pengenceran. Hasil pengenceran formula SNEDDS ditunjukkan pada tabel 9. Persyaratan uji pengenceran SNEDDS adalah dihasilkan emulsi yang bluish/jernih. $\mathrm{Smix}_{1}$ tidak memenuhi persyaratan, sementara $\mathrm{Smix}_{2}, \mathrm{Smix}_{3}$, dan $\mathrm{Smix}_{4}$ memenuhi persyaratan pada rasio fase minyak: Smix 1:9. $\mathrm{Smix}_{5}, \mathrm{Smix}_{6}, \mathrm{Smix}_{7}$ dan $\mathrm{Smix}_{8}$ memenuhi persyaratan pada rasio fase minyak: Smix 1:9, 2:8, dan 3:7.

Surfaktan yang digunakan pada penelitian ini adalah kombinasi Tween 80/Span 20 dan kombinasi Croduret 50SS/Span 80. Konsentrasi surfaktan diperoleh melalui perhitungan HLB dengan HLB butuh castor oil sebesar 14. Nilai HLB surfaktan yang tepat dapat mempengaruhi pembentukan emulsi dengan ukuran globul kecil. Nilai HLB surfaktan yang sesuai dengan HLB butuh minyak dapat memprediksi ketepatan penggunaan surfaktan tersebut. ${ }^{23}$ Hal ini sesuai dengan hasil yang diperoleh pada penelitian yaitu emulsi dapat terbentuk pada pembuatan SNEDDS menggunakan kombinasi surfaktan denga nnilai HLB campuran surfaktan sebesar 14 pada rasio surfaktan, kosurfaktan, dan fase minyak tertentu. Setelah dilarutkan dalam media aqueous, SNEDDS yang optimal harus menghasilkan emulsi yang jernih, transparan dan tidak menghasilkan pemisahan fase. Hal ini mengindikasikan bahwa sistem SNEDDS sesuai untuk pemberian secara per oral yang mana SNEDDS akan masuk ke saluran pencernaan dalam bentuk globul emulsi tanpa adanya pemisahan fase. Pada penelitian yang dilakukan Nasr et al. (2016), sebanyak $1 \mathrm{ml}$ formula SNEDDS Olmesartan diencerkan kedalam media aqueous sebanyak 10, 100, hingga 1000 kali dapat menghasilkan emulsi yang jernih dan tidak ada pemisahan fase. Formula SNEDDS Olmesartan dapat membentuk nanoemulsi yang stabil pada pengenceran dengan komposisi media aqueous hingga jumlah yang besar. ${ }^{22}$

Smix $_{1}$ tidak menghasilkan emulsi yang jernih saat dilakukan pengenceran dengan akuades, sementara pada $\mathrm{Smix}_{2}, \mathrm{Smix}_{3}$, dan $\mathrm{Smix}_{4}$ menghasilkan emulsi yang jernih pada rasio fase minyak:Smix 1:9. Hal ini disebabkan karena jika konsentrasi surfaktan ditingkatkan, seperti pada $\mathrm{Smix}_{2}$, terjadi penurunan tegangan antar permukaan dan peningkatan fluiditas antarmuka sehingga meningkatkan pembentukan nanoemulsi. ${ }^{24} \mathrm{Hal}$ ini menunjukkan bahwa pembentukan SNEDDS menggunakan surfaktan Tween
80-Span 20 sudah mencapai batas optimum pada perbandingan surfaktan:kosurfaktan 2:1. $\mathrm{Smix}_{5}, \mathrm{Smix}_{6}$, $\mathrm{Smix}_{7}$, dan $\mathrm{Smix}_{8}$ menghasilkan emulsi yang jernih hingga bluish pada rasio fase minyak:Smix 1:9, 2:8, dan 3:7. Hal ini menunjukkan bahwa SNEDDS dengan surfaktan Croduret 50SS-Span 80 mampu menghasilkan emulsifikasi spontan lebih baik dibandingkan surfaktan Tween 80-Span 20 karena pada peningkatan jumlah fase minyak hingga $30 \%$, masih terbentuk emulsi yang jernih. Croduret 50SS (PEG-40 hydrogenated

castor oil) memiliki panjang rantai karbon yang sama dengan castor oil, sehingga dapat membantu Croduret 50SS untuk terdispersi dalam droplet minyak secara merata. ${ }^{25}$ Struktur molekul campuran surfaktan pada lapisan antar permukaan fase minyak dan air juga merupakan faktor yang mempengaruhi pembentukan nanoemulsi setelah didispersikan dalam medium aqueous. Struktur alkil bercabang pada molekul Croduret serta nilai HLB 14,1 mengindikasikan bahwa Croduret termasuk surfaktan yang hidrofil. Surfaktan hidrofil akan terdispersi dan membentuk misel secara spontan dalam media aqueous sehingga membentuk globul berukuran submikron dan menghasilkan dispersi yang transparan. ${ }^{13}$ Secara penampakan visual, $\mathrm{Smix}_{8}$ lebih baik daripada $\mathrm{Smix}_{5}$, $\mathrm{Smix}_{6}$, dan $\mathrm{Smix}_{7}$ karena pada rasio fase minyak:Smix 3:7 menghasilkan emulsi jernih sementara pada $\mathrm{Smix}_{5}, \mathrm{Smix}_{6}$, dan $\mathrm{Smix}_{7}$ menghasilkan emulsi bluish. Peningkatan konsentrasi surfaktan dapat menurunkan tegangan permukaan, meningkatkan fleksibilitas lapisan surfaktan, dan meningkatkan entropi sistem sehingga meningkatkan pembentukan nanoemulsi. ${ }^{26}$

\begin{tabular}{|c|c|c|c|c|c|c|c|c|}
\hline Smix & & & & & & & & \\
\hline $\begin{array}{l}\text { Fase } \\
\text { minyak } \\
: \\
\text { Smix }\end{array}$ & Smix $_{1}$ & Smix $_{2}$ & $\mathrm{Smix}_{3}$ & Smix $_{4}$ & Smix $_{5}$ & Smix $_{6}$ & $\operatorname{Smix}_{7}$ & Smix $_{8}$ \\
\hline $1: 9$ & Keruh & Jernih & Jernih & Jernih & Jernih & Jernih & Jernih & Jernih \\
\hline $2: 8$ & Keruh & Keruh & Keruh & Keruh & Jernih & Jernih & Jernih & Jernih \\
\hline $3: 7$ & $\begin{array}{l}\text { Keruh } \\
\text {, } \\
\text { flokul } \\
\text { asi }\end{array}$ & Keruh & Keruh & Keruh & $\begin{array}{c}\text { Bluis } \\
\mathrm{h}\end{array}$ & $\begin{array}{c}\text { Bluis } \\
\mathrm{h}\end{array}$ & $\begin{array}{c}\text { Bluis } \\
\mathrm{h}\end{array}$ & Jernih \\
\hline $4: 6$ & $\begin{array}{l}\text { Keruh } \\
\text {, } \\
\text { flokul } \\
\text { asi }\end{array}$ & $\begin{array}{c}\text { Keruh } \\
\text {, ada } \\
\text { partik } \\
\text { el }\end{array}$ & $\begin{array}{l}\text { Keruh } \\
\text {, } \\
\text { flokul } \\
\text { asi }\end{array}$ & $\begin{array}{l}\text { Keruh } \\
\text {, } \\
\text { flokul } \\
\text { asi }\end{array}$ & $\begin{array}{l}\text { Keruh } \\
\text {, } \\
\text { flokul } \\
\text { asi }\end{array}$ & Keruh & Keruh & Keruh \\
\hline $5: 5$ & $\begin{array}{c}\text { Floku } \\
\text { lasi }\end{array}$ & $\begin{array}{c}\text { Keruh } \\
\text {, ada } \\
\text { partik } \\
\text { el }\end{array}$ & $\begin{array}{l}\text { Keruh } \\
\text {, } \\
\text { flokul } \\
\text { asi }\end{array}$ & $\begin{array}{l}\text { Keruh } \\
\text {, } \\
\text { flokul } \\
\text { asi }\end{array}$ & $\begin{array}{l}\text { Keruh } \\
\text {, } \\
\text { flokul } \\
\text { asi }\end{array}$ & Keruh & Keruh & Keruh \\
\hline $6: 4$ & $\begin{array}{l}\text { Keruh } \\
\text { flokul } \\
\text { asi }\end{array}$ & $\begin{array}{c}\text { Floku } \\
\text { lasi }\end{array}$ & $\begin{array}{c}\text { Floku } \\
\text { lasi }\end{array}$ & $\begin{array}{c}\text { Keruh } \\
\text {, } \\
\text { flokul } \\
\text { asi }\end{array}$ & $\begin{array}{c}\text { Keruh } \\
\text {, } \\
\text { flokul } \\
\text { asi }\end{array}$ & $\begin{array}{c}\text { Keruh } \\
\text {, } \\
\text { flokul } \\
\text { asi }\end{array}$ & Keruh & Keruh \\
\hline $7: 3$ & $\begin{array}{c}\text { Floku } \\
\text { lasi }\end{array}$ & $\begin{array}{c}\text { Floku } \\
\text { lasi }\end{array}$ & $\begin{array}{c}\text { Floku } \\
\text { lasi }\end{array}$ & $\begin{array}{c}\text { Floku } \\
\text { lasi }\end{array}$ & $\begin{array}{l}\text { Keruh } \\
\text { flokul } \\
\text { asi }\end{array}$ & $\begin{array}{l}\text { Keruh } \\
\text { flokul } \\
\text { asi }\end{array}$ & $\begin{array}{l}\text { Keruh } \\
\text {, } \\
\text { flokul } \\
\text { asi }\end{array}$ & $\begin{array}{l}\text { Keruh } \\
\text { flokul } \\
\text { asi }\end{array}$ \\
\hline $8: 2$ & $\begin{array}{l}\text { Keruh } \\
\text { flokul } \\
\text { asi }\end{array}$ & $\begin{array}{c}\text { Floku } \\
\text { lasi }\end{array}$ & $\begin{array}{c}\text { Floku } \\
\text { lasi }\end{array}$ & $\begin{array}{c}\text { Floku } \\
\text { lasi }\end{array}$ & $\begin{array}{l}\text { Keruh } \\
\text {, } \\
\text { flokul } \\
\text { asi }\end{array}$ & $\begin{array}{l}\text { Keruh } \\
\text { flokul } \\
\text { asi }\end{array}$ & $\begin{array}{l}\text { Keruh } \\
\text {, } \\
\text { flokul } \\
\text { asi }\end{array}$ & $\begin{array}{c}\text { Keruh } \\
\text {, } \\
\text { flokul } \\
\text { asi }\end{array}$ \\
\hline $9: 1$ & $\begin{array}{c}\text { Floku } \\
\text { lasi }\end{array}$ & $\begin{array}{c}\text { Floku } \\
\text { lasi }\end{array}$ & $\begin{array}{c}\text { Floku } \\
\text { lasi }\end{array}$ & $\begin{array}{c}\text { Floku } \\
\text { lasi }\end{array}$ & $\begin{array}{l}\text { Jernih } \\
\text { flokul } \\
\text { asi }\end{array}$ & $\begin{array}{l}\text { Jernih } \\
\text {, } \\
\text { flokul } \\
\text { asi }\end{array}$ & $\begin{array}{c}\text { Keruh } \\
\text {, } \\
\text { flokul } \\
\text { asi }\end{array}$ & $\begin{array}{c}\text { Keruh } \\
\text {, } \\
\text { flokul } \\
\text { asi }\end{array}$ \\
\hline
\end{tabular}




\section{2) Hasil Uji Persen Transmitansi}

Hasil persen transmitansi $\mathrm{Smix}_{5}, \mathrm{Smix}_{6}, \mathrm{Smix}_{7}$, dan $\mathrm{Smix}_{8}$ ditunjukkan pada Tabel 10. Persyaratan uji persen transmitansi adalah $>90 \%$. Berdasarkan hasil yang diperoleh, formula yang memenuhi persyaratan adalah Smix $_{5}$ (rasio fase minyak:Smix 1:9), Smix ${ }_{6}$ (rasio fase minyak:Smix 1:9 dan 2:8), $\operatorname{Smix}_{7}$ (rasio fase minyak:Smix 1:9 dan 2:8), dan $\mathrm{Smix}_{8}$ (rasio fase minyak:Smix 1:9 dan 2:8). Dari hasil analisis statistik Kruskal-Wallis Test, diperoleh nilai $\mathrm{p}=0,000 \quad(\mathrm{p}<0,005)$ yang menunjukkan bahwa terdapat perbedaan persen transmitansi yang bermakna antara kelompok yang diuji.

Tabel 10. Hasil Uji Persen Transmitansi

\begin{tabular}{|c|c|c|c|c|}
\hline \multirow{2}{*}{$\begin{array}{c}\text { Fase } \\
\text { minyak:Smix }\end{array}$} & \multicolumn{4}{|c|}{ Persen Transmitansi (Rata-rata \pm SD) $(n=6)$} \\
\hline & Smix $_{5}$ & Smix $_{6}$ & Smix $_{7}$ & Smix $_{8}$ \\
\hline $1: 9$ & $\begin{array}{l}87,97 \pm \\
3,18 \%\end{array}$ & $\begin{array}{c}91,23 \pm \\
1,89 \%\end{array}$ & $\begin{array}{c}95,77 \pm \\
1,42 \%\end{array}$ & $\begin{array}{c}97,03 \pm \\
1,30 \%\end{array}$ \\
\hline $2: 8$ & $\begin{array}{l}33,33 \pm \\
26,56 \%\end{array}$ & $\begin{array}{l}88,48 \pm \\
2,99 \%\end{array}$ & $\begin{array}{l}94,60 \pm \\
0,80 \%\end{array}$ & $\begin{array}{c}90,30 \pm \\
3,54 \%\end{array}$ \\
\hline $3: 7$ & $1,28 \pm 0,49 \%$ & $\begin{array}{c}55,25 \pm \\
2,01 \%\end{array}$ & $\begin{array}{c}60,18 \pm \\
7,17 \%\end{array}$ & $\begin{array}{l}76,65 \pm \\
4,54 \%\end{array}$ \\
\hline $4: 6$ & $0,17 \pm 0,05 \%$ & $\begin{array}{l}0,58 \pm \\
0,24 \%\end{array}$ & $\begin{array}{l}0,60 \pm \\
0,37 \%\end{array}$ & $\begin{array}{c}18,38 \pm \\
5,06 \%\end{array}$ \\
\hline $5: 5$ & $0,22 \pm 0,04 \%$ & $\begin{array}{l}0,20 \pm \\
0,00 \%\end{array}$ & $\begin{array}{l}0,65 \pm \\
0,62 \%\end{array}$ & $\begin{array}{l}2,77 \pm \\
2,11 \%\end{array}$ \\
\hline $6: 4$ & $0,15 \pm 0,05 \%$ & $\begin{array}{l}0,20 \pm \\
0,00 \%\end{array}$ & $\begin{array}{l}0,10 \pm \\
0,00 \%\end{array}$ & $\begin{array}{l}0,12 \pm \\
0,04 \%\end{array}$ \\
\hline $7: 3$ & $0,10 \pm 0,00 \%$ & $\begin{array}{l}0,10 \pm \\
0,00 \%\end{array}$ & $\begin{array}{l}0,22 \pm \\
0,04 \%\end{array}$ & $\begin{array}{l}0,20 \pm \\
0,06 \%\end{array}$ \\
\hline $8: 2$ & $0,10 \pm 0,00 \%$ & $\begin{array}{l}0,10 \pm \\
0,00 \%\end{array}$ & $\begin{array}{l}0,10 \pm \\
0,00 \%\end{array}$ & $\begin{array}{l}0,10 \pm \\
0,00 \%\end{array}$ \\
\hline
\end{tabular}

Persen transmitansi digunakan sebagai salah satu parameter untuk menentukan formula optimal karena semakin tinggi persen transmitansi, maka kemungkinan ukuran globul yang terbentuk semakin kecil. Nanoemulsi memiliki penampakan visual yang berbeda dengan emulsi konvensional karena ukuran globul nanoemulsi lebih kecil daripada panjang gelombang pada spektrum cahaya tampak. Nanoemulsi memiliki penampakan visual mendekati transparan pada spektrum cahaya tampak karena menyebarkan sangat sedikit cahaya tampak. Semakin kecil ukuran globul, maka semakin transparan emulsi yang terbentuk. Semakin besar ukuran globul, maka penyebaran cahaya tampak akan meningkat sehingga penampakan visual emulsi menjadi semakin keruh hingga putih. Transmitansi pada spektrum cahaya tampak mendekati $100 \%$ mengindikasikan derajat transparansi yang tinggi. ${ }^{27,28}$ Persyaratan yang ditetapkan untuk persen transmitansi formula SNEDDS yang optimal adalah $>90 \% .{ }^{15}$ Formula SNEDDS yang memenuhi persyaratan adalah formula $\mathrm{Smix}_{6}$ dengan rasio fase minyak:Smix 1:9 dan 2:8, formula $\mathrm{Smix}_{7}$ dengan rasio fase minyak:Smix 1:9 dan 2:8, serta formula $\mathrm{Smix}_{8}$ dengan rasio fase minyak:Smix 1:9 dan 2:8. Hal ini mengindikasikan bahwa formula SNEDDS tersebut memiliki ukuran globul dalam rentang ukuran nanometer yaitu 20-200 nm.

\section{3) Hasil Uji Waktu Emulsifikasi}

Hasil waktu emulsifikasi $\operatorname{Smix}_{5}, \operatorname{Smix}_{6}, \mathrm{Smix}_{7}$, dan $\mathrm{Smix}_{8}$ ditunjukkan pada Tabel 11. Persyaratan waktu emulsifikasi adalah $<60$ detik. ${ }^{12}$ Formula yang memenuhi persyaratan adalah $\operatorname{Smix}_{5}$ (rasio fase minyak:Smix 1:9), $\mathrm{Smix}_{6}$ (rasio fase minyak:Smix 1:9 dan 2:8), dan $\mathrm{Smix}_{7}$ (rasio fase minyak:Smix 1:9). Dari hasil uji One Way ANOVA diperoleh nilai $\mathrm{p}=0,000(\mathrm{p}<0,05)$ untuk uji waktu emulsifikasi dalam akuades dan dari hasil Kruskal-Wallis Test diperoleh nilai $\mathrm{p}=0,000(\mathrm{p}<0,05)$ untuk uji waktu emulsifikasi dalam $\mathrm{HCl} 0,1 \mathrm{~N}$. Hal ini menunjukkan bahwa terdapat perbedaan waktu emulsifikasi yang bermakna antara kelompok yang diuji.

Waktu emulsifikasi diukur untuk memperkirakan efisiensi emulsifikasi spontan. SNEDDS harus terdispersi seluruhnya secara cepat saat dicampurkan dalam media aqueous dengan sedikit pengadukan. ${ }^{29}$ Waktu emulsifikasi semakin meningkat dari $\mathrm{Smix}_{5}, \mathrm{Smix}_{6}, \mathrm{Smix}_{7}$, hingga $\mathrm{Smix}_{8}$. Hal ini menunjukkan bahwa peningkatan konsentrasi surfaktan menyebabkan spontanitas proses pembentukan emulsi menjadi lebih lambat. Hal ini disebabkan karena surfaktan jenis polyoxyl seperti Croduret 50SS dalam konsentrasi yang tinggi akan membentuk fase gel. Zeng et al. membuat nanoemulsi dengan surfaktan Cremophor EL dan memperoleh hasil terbentuk fase gel saat konsentrasi surfaktan ditingkatkan menjadi Smix 3:1. Pembentukan emulsifikasi spontan menurun akibat peningkatan fase gel pada Smix 4:1. Pembentukan fase gel menyebabkan dispersi SNEDDS dalam media aqueous untuk membentuk emulsi yang homogen memerlukan waktu lebih lama. ${ }^{26}$ Penggunaan kosurfaktan juga mempengaruhi spontanitas

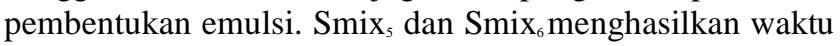
emulsifikasi yang lebih cepat daripada $\mathrm{Smix}_{7}$ dan $\mathrm{Smix}_{8}$.

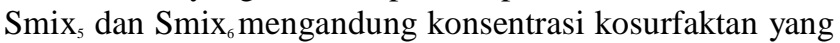
lebih tinggi daripada $\mathrm{Smix}_{7}$ dan $\mathrm{Smix}_{8}$. Kombinasi surfaktan dan kosurfaktan dapat meningkatkan fleksibilitas lapisan surfaktan, menurunkan tegangan antar permukaan, dan meningkatkan entropi sistem sehingga pembentukan nanoemulsi menjadi lebih mudah dan spontanitas emulsifikasi meningkat. ${ }^{26}$

\begin{tabular}{|c|c|c|c|c|}
\hline \multicolumn{5}{|c|}{ Tabel 11. Hasil Uji Waktu Emulsifikasi } \\
\hline \multirow[t]{2}{*}{ Smix } & \multirow{2}{*}{$\begin{array}{c}\text { Fase } \\
\text { minyak: } \\
\text { Smix }\end{array}$} & \multicolumn{2}{|c|}{$\begin{array}{c}\text { Waktu Emulsifikasi } \\
(\text { Rata-rata (detik) } \pm \text { SD }) \\
(n=6)\end{array}$} & \multirow{2}{*}{$\begin{array}{c}\text { Penampakan } \\
\text { Visual }\end{array}$} \\
\hline & & $\begin{array}{c}\text { Dalam } \\
\text { akuades }\end{array}$ & $\begin{array}{c}\text { Dalam } \\
\text { HCl 0,1 N }\end{array}$ & \\
\hline \multirow{3}{*}{$\operatorname{Smix}_{5}$} & $1: 9$ & $\begin{array}{c}13,90 \pm \\
1,05\end{array}$ & $\begin{array}{c}11,45 \pm \\
0,18\end{array}$ & Jernih \\
\hline & $2: 8$ & $\begin{array}{c}34,54 \pm \\
2,62\end{array}$ & $\begin{array}{c}20,93 \pm \\
4,24\end{array}$ & Keruh \\
\hline & $3: 7$ & $\begin{array}{c}17,47 \pm \\
1,77\end{array}$ & $\begin{array}{c}32,00 \pm \\
0,43\end{array}$ & Keruh \\
\hline \multirow{3}{*}{$\operatorname{Smix}_{6}$} & $1: 9$ & $\begin{array}{c}15,19 \pm \\
3,60\end{array}$ & $\begin{array}{c}13,93 \pm \\
2,34\end{array}$ & Jernih \\
\hline & $2: 8$ & $\begin{array}{c}24,89 \pm \\
8,42\end{array}$ & $\begin{array}{c}36,12 \pm \\
2,96\end{array}$ & Bluish \\
\hline & $3: 7$ & $\begin{array}{c}55,59 \pm \\
3,21\end{array}$ & $\begin{array}{c}38,89 \pm \\
3,38\end{array}$ & Keruh \\
\hline \multirow{3}{*}{$\operatorname{Smix}_{7}$} & $1: 9$ & $\begin{array}{c}45,72 \pm \\
1,69\end{array}$ & $\begin{array}{c}14,72 \pm \\
1,24\end{array}$ & Jernih \\
\hline & $2: 8$ & $\begin{array}{c}64,25 \pm \\
6,06\end{array}$ & $\begin{array}{c}69,81 \pm \\
5,30\end{array}$ & Bluish \\
\hline & $3: 7$ & $\begin{array}{c}44,97 \pm \\
7,08\end{array}$ & $\begin{array}{c}82,17 \pm \\
3,72\end{array}$ & Keruh \\
\hline $\mathrm{Smix}_{8}$ & $1: 9$ & $\begin{array}{c}116,37 \pm \\
5,27\end{array}$ & $\begin{array}{c}76,98 \pm \\
6,80\end{array}$ & Jernih \\
\hline
\end{tabular}




\begin{tabular}{cccc}
\hline $2: 8$ & $137,65 \pm$ & $116,22 \pm$ & Bluish \\
& 8,14 & 2,85 & \\
\hline $3: 7$ & $135,85 \pm$ & $158,49 \pm$ & Keruh \\
& 8,70 & 11,29 & \\
\hline
\end{tabular}

\section{Hasil Evaluasi SNEDDS Nifedipin}

Berdasarkan hasil optimasi formula, formula yang prospektif adalah formula $\mathrm{Smix}_{6}$ dengan rasio fase minyak:Smix 1:9 (F1), formula $\mathrm{Smix}_{6}$ dengan rasio fase minyak:Smix 2:8 (F2), dan formula $\mathrm{Smix}_{7}$ dengan rasio fase minyak:Smix 1:9 (F3). Formula Smix ${ }_{5}$ tidak stabil karena terjadi pemisahan. F1, F2, dan F3 ditambahkan nifedipin dan dilakukan uji evaluasi sediaan. Sediaan SNEDDS nifedipin homogen, berwarna kuning, jernih, kental, dan memiliki aroma khas SNEDDS. Pada uji pengenceran SNEDDS, diperoleh emulsi yang jernih pada ketiga formula.

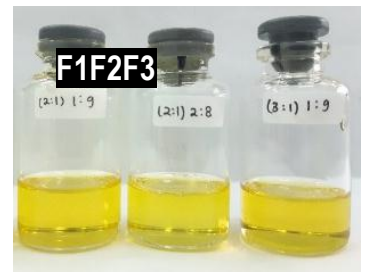

Gambar 1. SNEDDS Nifedipin

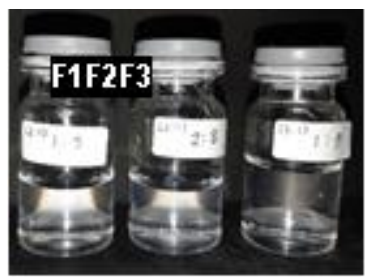

Gambar 2. Hasil Pengenceran SNEDDS Nifedipin

\section{Hasil Uji Persen Transmitansi}

Hasil uji persen transmitansi F1, F2, dan F3 ditunjukkan pada tabel 12. F1, F2, dan F3 memenuhi persyaratan persen transmitansi. Dari hasil uji One Way ANOVA diperoleh nilai $\mathrm{p}=0,000 \quad(\mathrm{p}<0,05)$ yang menunjukkan bahwa terdapat perbedaan persen transmitansi yang bermakna antara F1, F2, dan F3. Hasil uji Paired T-Test persen transmitansi sebelum dan sesudah ditambahkan nifedipin pada F1, F2, dan F3 berturut-turut diperoleh nilai $\mathrm{p}=0,000 ; \mathrm{p}=0,023$; dan $\mathrm{p}=0,007$.

Formula SNEDDS yang prospektif, yaitu F1, F2, dan F3 menghasilkan SNEDDS yang homogen, berwarna kuning, jernih, kental, dan memiliki aroma khas SNEDDS. Pada uji pengenceran, diperoleh emulsi yang jernih (transparan). Nanoemulsi memiliki penampakan visual yang transparan dan agak bluish karena menyebarkan cahaya dengan panjang gelombang rendah. ${ }^{28} \mathrm{~F} 1, \mathrm{~F} 2$, dan F3 menghasilkan persen transmitansi yang masuk dalam persyaratan. Nilai persen transmitansi yang mendekati $100 \%$ mengindikasikan sifat isotropik pada sistem yang terbentuk serta mengindikasikan ukuran globul berada pada rentang nanometer. ${ }^{31}$
Tabel 12. Hasil Persen Transmitansi SNEDDS Nifedipin

Formula Persen transmitansi (Rata-rata \pm SD) $(n=6)$

\begin{tabular}{ll}
\hline F1 & $\mathbf{9 8 , 3 7} \pm \mathbf{0 , 4 9 \%}$ \\
\hline F2 & $\mathbf{9 3 , 5 2} \pm \mathbf{0 , 9 9 8} \%$ \\
\hline F3 & $\mathbf{9 8 , 3 5} \pm \mathbf{0 , 1 2 \%}$ \\
\hline
\end{tabular}

\section{Hasil Uji Waktu Emulsifikasi}

Hasil uji waktu emulsifikasi F1, F2, dan F3 ditunjukkan pada tabel 13. F1, F2, dan F3 memenuhi persyaratan waktu emulsifikasi. F1 menghasilkan waktu emulsifikasi dalam akuades yang lebih cepat daripada F2 dan F3, sedangkan waktu emulsifikasi F3 lebih cepat daripada F2 baik dalam akuades maupun $\mathrm{HCl} 0,1 \mathrm{~N}$. Dari hasil uji One Way ANOVA diperoleh nilai $\mathrm{p}=0,000(\mathrm{p}<0,05)$ untuk waktu emulsifikasi dalam akuades dan dalam $\mathrm{HCl} 0,1 \mathrm{~N}$. Hal ini menunjukkan bahwa terdapat perbedaan waktu emulsifikasi yang bermakna antara F1, F2, dan F3. Dari hasil uji Paired T-Test waktu emulsifikasi dalam akuades sebelum dan sesudah ditambahkan nifedipin pada F1, F2, dan F3 berturut-turut diperoleh nilai $p=0,378 ; p=0,020$; dan $\mathrm{p}=0,000$. Dari hasil uji Paired T-Test waktu emulsifikasi dalam $\mathrm{HCl} 0,1 \mathrm{~N}$ sebelum dan sesudah ditambahkan nifedipin pada $\mathrm{F} 1, \mathrm{~F} 2$, dan $\mathrm{F} 3$ berturut-turut diperoleh nilai $\mathrm{p}=0,022 ; \mathrm{p}=0,000 ;$ dan $\mathrm{p}=0,390$.

Tabel 13. Hasil Waktu Emulsifikasi SNEDDS Nifedipin Waktu Emulsifikasi

(Rata-rata (detik) \pm SD)

\begin{tabular}{cccc} 
Formula & \multicolumn{2}{c}{$\begin{array}{c}\text { Waktu Emulsifikasi } \\
\text { (Rata-rata }(\text { detik) } \pm \text { SD) } \\
(\mathbf{n = 6})\end{array}$} & Penampakan Visual \\
\cline { 2 - 3 } & $\begin{array}{c}\text { Dalam } \\
\text { akuades }\end{array}$ & $\begin{array}{c}\text { Dalam HCl } \\
\mathbf{0 , 1} \mathbf{~ N}\end{array}$ & \\
\hline F1 & $14,09 \pm 1,05$ & $11,38 \pm 0,66$ & $\begin{array}{c}\text { jernih, berwarna } \\
\text { kekuningan }\end{array}$ \\
\hline F2 & $36,80 \pm 2,41$ & $21,58 \pm 1,19$ & $\begin{array}{c}\text { agak bluish, berwarna } \\
\text { kekuningan }\end{array}$ \\
\hline F3 & $15,47 \pm 1,31$ & $14,09 \pm 1,91$ & $\begin{array}{c}\text { jernih, berwarna } \\
\text { kekuningan }\end{array}$ \\
\hline
\end{tabular}

Waktu emulsifikasi F1, F2, dan F3 dalam akuades maupun $\mathrm{HCl} 0,1 \mathrm{~N}$ juga memenuhi persyaratan. Emulsi yang jernih atau agak bluish dengan waktu emulsifikasi yang cepat menunjukkan bahwa formula SNEDDS mengalami proses emulsifikasi dengan mudah. Kemampuan emulsifikasi spontan merupakan karakteristik yang penting untuk SNEDDS karena proses emulsifikasi merupakan rate limiting process untuk absorpsi obat. Emulsifikasi spontan terjadi ketika ada perubahan entropi saat dispersi lebih besar daripada energi yang dibutuhkan untuk meningkatkan luas permukaan antara minyak dan fase aqueous. Pada sistem self-emulsifying, saat fase minyak dimasukkan ke dalam fase aqueous dengan pengadukan ringan, fase aqueous akan berpenetrasi melalui lapisan antar permukaan ke fase minyak hingga lapisan kedua fase rusak dan terbentuk globul-globul minyak dalam air. ${ }^{31}$ Waktu emulsifikasi bergantung pada perbandingan konsentrasi minyak, surfaktan, dan kosurfaktan. F1 dan F2 merupakan formula dengan Smix yang sama yaitu Smix 2:1. F2 menghasilkan waktu emulsifikasi yang lebih lama daripada F1. Semakin tinggi konsentrasi surfaktan, maka proses emulsifikasi spontan akan meningkat dilihat dari waktu emulsifikasi yang 
menurun. Hal ini dapat disebabkan karena kapasitas surfaktan dalam menurunkan tegangan antar permukaan menurun. ${ }^{22}$

Terdapat perbedaan secara bermakna persen transmitansi dan waktu emulsifikasi F1, F2, dan F3 berbeda sebelum dan sesudah ditambahkan nifedipin. Persen transmitansi sesudah ditambahkan nifedipin lebih tinggi daripada sebelum ditambahkan nifedipin, sementara waktu emulsifikasi sesudah ditambahkan nifedipin lebih cepat daripada sebelum ditambahkan nifedipin. Hal ini dapat disebabkan karena prosedur pencampuran SNEDDS tanpa nifedipin dan dengan nifedipin membutuhkan waktu yang berbeda. Pencampuran SNEDDS dengan nifedipin lebih lama daripada tanpa nifedipin. Energi mekanik yang diberikan pada formula dengan nifedipin lebih besar sehingga dapat memecah molekul surfaktan dan mendistribusikannya dalam sistem. Oleh karena itu, globul menjadi lebih mudah terdispersi pada fase aqueous dan menurunkan waktu emulsifikasi. ${ }^{34}$

\section{Hasil Uji Ukuran Globul dan Indeks Polidispersitas} Hasil uji ukuran globul dan indeks polidispersitas F1, F2, dan F3 ditunjukkan pada tabel 14.

Tabel 14. Hasil Ukuran Globul dan Indeks Polidispersitas SNEDDS Nifedipin

\begin{tabular}{ccc} 
& \multicolumn{1}{c}{ Nifedipin } & \\
Formula & $\begin{array}{c}\text { Ukuran Globul }(\text { Rata-rata }(\mathbf{n m}) \pm \\
\text { SD) }(\mathbf{n}=\mathbf{3})\end{array}$ & $\begin{array}{c}\text { Indeks } \\
\text { Polidispersitas } \\
(\text { Rata-rata } \pm \text { SD) } \\
(\mathbf{n}=\mathbf{3})\end{array}$ \\
\hline F1 & $24,05 \pm 0,02$ & $0,277 \pm 0,0038$ \\
\hline F2 & $41,69 \pm 0,106$ & $0,396 \pm 0,0025$ \\
\hline F3 & $32,37 \pm 0,420$ & $0,442 \pm 0,0104$ \\
\hline
\end{tabular}

F1, F2, dan F3 menghasilkan ukuran globul yang memenuhi rentang ukuran nanometer yaitu 20-200 nm. Indeks polidispersitas F1, F2, dan F3 kurang dari 0,5. Ukuran globul F1 lebih kecil daripada F2 dan F3, dan ukuran globul F2 lebih besar daripada F3. Indeks polidispersitas ketiga formula makin meningkat dari F1, F2, dan F3. Dari uji One Way ANOVA diperoleh hasil nilai $\mathrm{p}=0,000 \quad(\mathrm{p}<0,05)$ yang menunjukkan bahwa terdapat perbedaan ukuran globul yang bermakna antara F1, F2, dan F3. Ukuran globul F1, F2, dan F3 masuk ke dalam rentang ukuran nanometer yaitu 20-200 nm. Ukuran globul merupakan karakteristik yang penting pada SNEDDS karena akan menentukan kecepatan dan tingkat pelepasan hingga absorpsi obat. Semakin kecil ukuran partikel, maka semakin besar luas permukaan partikel sehingga akan mempercepat absorpsi dan meningkatkan bioavailabilitas. Ukuran globul yang kecil dipengaruhi oleh surfaktan dan kosurfaktan yang digunakan. Surfaktan dan kosurfaktan dapat menurunkan energi bebas pada sistem sehingga akan mencegah ketidakstabilan termodinamika pada perubahan $\mathrm{pH}$ dan volume. Campuran surfaktan dan kosurfaktan juga memberikan barrier mekanik yang melindungi globul supaya tidak mengalami agregrasi dengan globul lain..$^{32}$

F1 memiliki ukuran globul yang lebih kecil daripada F2, yang mana F1 mengandung konsentrasi surfaktan yang lebih tinggi daripada F2. Penurunan tegangan antar permukaan lebih baik pada konsentrasi surfaktan yang lebih tinggi. Surfaktan yang lebih banyak juga akan meningkatkan difusi fase aqueous sehingga meningkatkan pembentukan globul berukuran kecil. ${ }^{26}$ Selain itu, dengan meningkatnya jumlah surfaktan, maka akan lebih banyak molekul surfaktan yang teradsorpsi dan membentuk lapisan surfaktan yang lebih rapat antara permukaan fase aqueous dan fase minyak. Kemudian akan terbentuk lapisan antar permukaan yang stabil dan padat serta tegangan antar permukaan yang rendah sehingga ukuran globul menjadi lebih kecil. ${ }^{22,33} \mathrm{~F} 1$ juga memiliki ukuran globul yang lebih kecil daripada F3, yang mana F1 mengandung Smix dengan perbandingan 2:1 sedangkan F3 mengandung Smix dengan perbandingan 3:1. Pada pembuatan nanoemulsi dengan isopropil miristat sebagai fase minyak, konsentrasi surfaktan yang melebihi konsentrasi tertentu akan membentuk fase kristalin cair dengan viskositas tinggi. Fase kristalin cair ini menghasilkan ukuran globul yang lebih tinggi pada nanoemulsi karena memiliki lapisan antar permukaan yang lebih kaku. ${ }^{23}$ Fase kristalin yang kental menyebabkan pemecahan secara spontan pada lapisan antar permukaan air dan minyak menjadi lebih sulit. ${ }^{34}$ Pembentukan fase kristal yang kental juga menurunkan kemampuan emulsifikasi spontan dan membutuhkan lebih banyak energi untuk membentuk dispersi yang kecil. ${ }^{35}$ Hal ini sesuai dengan hasil waktu emulsifikasi, yang mana F3 menghasilkan waktu emulsifikasi yang sedikit lebih lambat daripada F1.

F1, F2, dan F3 menghasilkan indeks polidispersitas kurang dari 0,5. Indeks polidispersitas menggambarkan distribusi ukuran partikel. Indeks polidispersitas mengukur homogenitas partikel. Indeks polidispersitas memiliki rentang dari 0,0 ke 1,0 . Nilai indeks polidispersitas yang kecil mengindikasikan globul yang homogen dan distribusi ukuran partikel yang sempit. Hal ini dapat mempengaruhi pada emulsi yang seragam dengan stabilitas fisik yang lebih tinggi. ${ }^{22}$

\section{Hasil Uji Stabilitas}

Hasil pengamatan organoleptik SNEDDS pada uji stabilitas termodinamika ditunjukkan pada tabel 15. F1 dan F3 stabil pada uji heating cooling cycle, uji sentrifugasi, dan uji freeze-thaw, sedangkan F2 tidak stabil setelah uji heating cooling cycle sehingga tidak dilakukan pengujian selanjutnya. Hasil uji persen transmitansi dan waktu emulsifikasi sesudah uji stabilitas ditunjukkan pada tabel 16. Persen transmitansi F1 dan F3 lebih tinggi sesudah uji stabilitas termodinamika dibanding sebelum uji stabilitas termodinamika tetapi masih memenuhi syarat. Waktu emulsifikasi F1 dan F3 sesudah uji stabilitas termodinamika juga memenuhi syarat. Dari hasil Paired $T$ Test persen transmitansi sebelum dan sesudah uji stabilitas termodinamika, untuk $\mathrm{F} 1$ diperoleh nilai $\mathrm{p}=0,057$ dan untuk F2 diperoleh nilai $\mathrm{p}=0,003$. Dari hasil Paired T-Test waktu emulsifikasi dalam akuades sebelum dan sesudah uji stabilitas termodinamika, untuk F1 diperoleh nilai $\mathrm{p}=0,003$ dan untuk F3 diperoleh nilai $\mathrm{p}=0,002$, sementara analisis hasil waktu emulsifikasi dalam $\mathrm{HCl} 0,1$ untuk $\mathrm{F} 1$ diperoleh nilai $\mathrm{p}=0,000$ dan untuk F3 diperoleh nilai $\mathrm{p}=0,011$. Hasil pengamatan organoleptik uji stabilitas on going 
ditunjukkan pada tabel 17. Berdasarkan hasil yang didapat, F1 dan F3 stabil pada penyimpanan selama 30 hari, sedangkan F2 tidak stabil yang ditunjukkan dengan adanya pemisahan pada sediaan. Uji stabilitas termodinamika yang dilakukan yaitu uji heating-cooling cycle, uji sentrifugasi, dan uji freeze thaw. Dari uji heating-cooling cycle diperoleh hasil bahwa F1 dan F3 stabil sementara F2 tidak stabil karena terdapat pemisahan dan gumpalan/flokulasi. Hal ini menunjukkan bahwa pada F2 komponen SNEDDS menjadi tidak homogen dan kemungkinan dosis nifedipin menjadi tidak seragam sehingga F2 tidak dilanjutkan untuk pengujian selanjutnya. Dari uji sentrifugasi dan freeze-thaw diperoleh hasil bahwa formula F1 dan F3 stabil. Persen transmitansi F1 dan F3 sesudah uji stabilitas termodinamika masuk dalam rentang yang dipersyaratkan yaitu 90-100\%. Hasil uji waktu emulsifikasi F1 dan F3 baik dalam akuades dan dalam $\mathrm{HCl} 0,1$ sesudah uji stabilitas termodinamik memenuhi persyaratan yang ditetapkan. Kedua formula dapat membentuk nanoemulsi yang jernih secara cepat. Terdapat perbedaan yang bermakna pada hasil persen transmitansi dan waktu emulsifikasi formula SNEDDS sebelum dan sesudah uji stabilitas termodinamika. Tetapi persen transmitansi dan waktu emulsifikasi sesudah uji stabilitas termodinamika masih memenuhi syarat. Hal ini menunjukkan bahwa F1 dan F3 stabil secara termodinamika. Uji stabilitas on going dilakukan untuk mengamati kestabilan sediaan selama penyimpanan dalam suhu ruang. Hasil yang diperoleh yaitu F1 dan F3 stabil sementara F2 tidak stabil pada penyimpanan di suhu ruang selama 30 hari.

Tabel 15. Hasil Uji Organoleptik Uji Stabilitas Termodinamika Pengamatan Organoleptik

\begin{tabular}{|c|c|c|c|}
\hline \multirow[b]{2}{*}{ Formula } & \\
\hline & $\begin{array}{l}\text { Uji heating- } \\
\text { cooling cycle }\end{array}$ & Uji sentrifugasi & Uji freeze-thaw \\
\hline F1 & \begin{tabular}{l}
\multicolumn{2}{l}{ Homogen, } \\
jernih, berwarna \\
kuning, kental, \\
berbau khas \\
SNEDDS \\
nifedipin
\end{tabular} & $\begin{array}{lr}\text { Homogen, } & \text { tidak } \\
\text { ada } & \text { endapan, } \\
\text { jernih, } & \text { berwarna } \\
\text { kuning, } & \text { kental, } \\
\text { berbau } & \text { khas } \\
\text { SNEDDS nifedipin }\end{array}$ & $\begin{array}{lr}\text { Homogen, tidak } \\
\text { ada pemisahan, } \\
\text { tidak ada endapan, } \\
\text { jernih, berwarna } \\
\text { kuning, kental, } \\
\text { berbau r khas } \\
\text { SNEDDS nifedipin }\end{array}$ \\
\hline F2 & $\begin{array}{l}\text { Memisah, } \\
\text { terdapat } \\
\text { gumpalan } \\
\text { partikel, } \\
\text { berwarna } \\
\text { kuning, kental, } \\
\text { berbau khas } \\
\text { SNEDDS } \\
\text { nifedipin }\end{array}$ & - & - \\
\hline F3 & \begin{tabular}{l}
\multicolumn{2}{l}{ Homogen, } \\
jernih, berwarna \\
kuning, kental, \\
berbau khas \\
SNEDDS \\
nifedipin
\end{tabular} & $\begin{array}{lr}\text { Homogen, } & \text { tidak } \\
\text { ada } & \text { endapan, } \\
\text { jernih, } & \text { berwarna } \\
\text { kuning, } & \text { kental, } \\
\text { berbau } & \text { khas } \\
\text { SNEDDS nifedipin }\end{array}$ & $\begin{array}{lr}\text { Homogen, tidak } \\
\text { ada pemisahan, } \\
\text { tidak ada endapan, } \\
\text { jernih, berwarna } \\
\text { kuning, kental, } \\
\text { berbau r khas } \\
\text { SNEDDS nifedipin }\end{array}$ \\
\hline
\end{tabular}

Tabel 16. Hasil Karakterisasi SNEDDS Sesudah Uji Stabilitas Termodinamika

\begin{tabular}{cccc} 
& & \multicolumn{2}{c}{ Waktu Emulsifikasi (Rata- } \\
Formula & Persen Transmitansi & \multicolumn{2}{c}{ rata (detik) \pm SD) $(\mathbf{n}=6)$} \\
\cline { 3 - 4 } & $($ Rata-rata \pm SD) $(\mathbf{n}=6)$ & Dalam & Dalam HCl \\
& & Akuades & $\mathbf{0 , 1} \mathbf{~ N}$
\end{tabular}

\begin{tabular}{|c|c|c|c|c|}
\hline F1 & \multirow{2}{*}{\multicolumn{2}{|c|}{$\begin{array}{l}98,97 \pm 0,41 \% \\
99,00 \pm 0,21 \%\end{array}$}} & $11,42 \pm 0,31$ & $7,03 \pm 0,41$ \\
\hline F3 & & & $11,96 \pm 0,62$ & $10,25 \pm 1,40$ \\
\hline \multicolumn{5}{|c|}{ Tabel 17. Hasil Uji Stabilitas On Going } \\
\hline \multirow{2}{*}{ Formula } & \multicolumn{4}{|c|}{ Pengamatan Organoleptik } \\
\hline & Hari ke-0 & Hari ke-14 & Hari ke-21 & Hari ke 30 \\
\hline F1 & $\begin{array}{l}\text { Homogen, } \\
\text { jernih, } \\
\text { berwarna } \\
\text { kuning, } \\
\text { kental, } \\
\text { berbau khas } \\
\text { SNEDDS } \\
\text { nifedipin }\end{array}$ & $\begin{array}{l}\text { Homogen, } \\
\text { jernih, } \\
\text { berwarna } \\
\text { kuning, } \\
\text { kental, berbau } \\
\text { khas } \\
\text { SNEDDS } \\
\text { nifedipin }\end{array}$ & $\begin{array}{l}\text { Homogen, } \\
\text { jernih, } \\
\text { berwarna } \\
\text { kuning, } \\
\text { kental, berbau } \\
\text { khas } \\
\text { SNEDDS } \\
\text { nifedipin }\end{array}$ & $\begin{array}{l}\text { Homogen, } \\
\text { jernih, } \\
\text { berwarna } \\
\text { kuning, } \\
\text { kental, berbau } \\
\text { khas } \\
\text { SNEDDS } \\
\text { nifedipin }\end{array}$ \\
\hline F2 & $\begin{array}{l}\text { Homogen, } \\
\text { jernih, } \\
\text { berwarna } \\
\text { kuning, } \\
\text { kental, } \\
\text { berbau khas } \\
\text { SNEDDS } \\
\text { nifedipin }\end{array}$ & $\begin{array}{l}\text { Terdapat } \\
\text { pemisahan, } \\
\text { berwarna } \\
\text { kuning, } \\
\text { kental, berbau } \\
\text { khas } \\
\text { SNEDDS } \\
\text { nifedipin }\end{array}$ & $\begin{array}{l}\text { Terdapat } \\
\text { pemisahan, } \\
\text { berwarna } \\
\text { kuning, } \\
\text { kental, berbau } \\
\text { khas } \\
\text { SNEDDS } \\
\text { nifedipin }\end{array}$ & $\begin{array}{l}\text { Terdapat } \\
\text { pemisahan, } \\
\text { berwarna } \\
\text { kuning, } \\
\text { kental, berbau } \\
\text { khas } \\
\text { SNEDDS } \\
\text { nifedipin }\end{array}$ \\
\hline F3 & $\begin{array}{l}\text { Homogen, } \\
\text { jernih, } \\
\text { berwarna } \\
\text { kuning, } \\
\text { kental, } \\
\text { berbau khas } \\
\text { SNEDDS } \\
\text { nifedipin }\end{array}$ & $\begin{array}{l}\text { Homogen, } \\
\text { jernih, } \\
\text { berwarna } \\
\text { kuning, } \\
\text { kental, berbau } \\
\text { khas } \\
\text { SNEDDS } \\
\text { nifedipin }\end{array}$ & $\begin{array}{l}\text { Homogen, } \\
\text { jernih, } \\
\text { berwarna } \\
\text { kuning, } \\
\text { kental, berbau } \\
\text { khas } \\
\text { SNEDDS } \\
\text { nifedipin }\end{array}$ & $\begin{array}{l}\text { Homogen, } \\
\text { jernih, } \\
\text { berwarna } \\
\text { kuning, } \\
\text { kental, berbau } \\
\text { khas } \\
\text { SNEDDS } \\
\text { nifedipin }\end{array}$ \\
\hline
\end{tabular}

\section{Hasil Uji Loading Dose Capacity}

Formula SNEDDS F1 ditambahkan nifedipin dengan dosis $30 \mathrm{mg} / \mathrm{g} ; 40 \mathrm{mg} / \mathrm{g} ; 50 \mathrm{mg} / \mathrm{g} ; 60 \mathrm{mg} / \mathrm{g} ; 70$ $\mathrm{mg} / \mathrm{g} ; 80 \mathrm{mg} / \mathrm{g}$; dan $90 \mathrm{mg} / \mathrm{g}$ kemudian disentrifugasi. Hasil uji loading dose capacity ditunjukkan pada tabel 18. Formula SNEDDS F1 menunjukkan loading obat maksimal sebesar $50 \mathrm{mg} / \mathrm{g}$. Pada penambahan nifedipin dengan dosis $50 \mathrm{mg}$, nanoemulsi dapat mempertahankan globul tetap terdispersi setelah disentrifugasi. Hal ini menunjukkan bahwa kestabilan fisik nanoemulsi baik pada penambahan dosis $50 \mathrm{mg}$

Tabel 18. Hasil Uji Loading Dose Capacity

\begin{tabular}{|c|c|c|}
\hline \multirow{2}{*}{$\begin{array}{l}\text { Dosis } \\
\text { Nifedipin }\end{array}$} & \multicolumn{2}{|r|}{ Hasil } \\
\hline & Sebelum Sentrifugasi & Sesudah sentrifugasi \\
\hline $30 \mathrm{mg} / \mathrm{g}$ & $\begin{array}{l}\text { Jernih, berwarna } \\
\text { kekuningan, tidak ada } \\
\text { endapan }\end{array}$ & $\begin{array}{l}\text { Jernih, berwarna kekuningan, } \\
\text { tidak ada endapan }\end{array}$ \\
\hline $40 \mathrm{mg} / \mathrm{g}$ & $\begin{array}{l}\text { Jernih, berwarna } \\
\text { kekuningan, tidak ada } \\
\text { endapan }\end{array}$ & $\begin{array}{l}\text { Jernih, berwarna kekuningan, } \\
\text { tidak ada endapan }\end{array}$ \\
\hline $50 \mathrm{mg} / \mathrm{g}$ & $\begin{array}{l}\text { Jernih, berwarna kuning } \\
\text { lebih pekat, tidak ada } \\
\text { endapan }\end{array}$ & $\begin{array}{l}\text { Jernih, berwarna kuning, tidak } \\
\text { ada endapan }\end{array}$ \\
\hline $60 \mathrm{mg} / \mathrm{g}$ & $\begin{array}{l}\text { Agak keruh, berwarna } \\
\text { kuning, tidak ada } \\
\text { endapan }\end{array}$ & $\begin{array}{l}\text { Terdapat endapan, supernatan } \\
\text { berwarna kuning }\end{array}$ \\
\hline $70 \mathrm{mg} / \mathrm{g}$ & $\begin{array}{l}\text { Agak keruh, berwarna } \\
\text { kuning, terdapat } \\
\text { flokulasi }\end{array}$ & $\begin{array}{l}\text { Terdapat endapan, supernatan } \\
\text { berwarna agak kekuningan dan } \\
\text { terdapat flokulasi }\end{array}$ \\
\hline $80 \mathrm{mg} / \mathrm{g}$ & $\begin{array}{l}\text { Agak keruh, berwarna } \\
\text { kuning, terdapat } \\
\text { flokulasi }\end{array}$ & $\begin{array}{l}\text { Terdapat endapan, supernatan } \\
\text { berwarna kekuningan dan } \\
\text { terdapat flokulasi }\end{array}$ \\
\hline $90 \mathrm{mg} / \mathrm{g}$ & $\begin{array}{l}\text { Berwarna kekuningan, } \\
\text { terdapat flokulasi }\end{array}$ & $\begin{array}{l}\text { Terdapat endapan, supernatan } \\
\text { berwarna kekuningan dan } \\
\text { terdapat flokulasi }\end{array}$ \\
\hline
\end{tabular}




\section{Hasil Uji pH}

Hasil uji pH F1 sebesar 6,97 $\pm 0,035$. Berdasarkan hasil yang didapatkan, $\mathrm{pH}$ SNEDDS $\mathrm{F} 1$ memenuhi persyaratan untuk sediaan oral yaitu $5-8 .{ }^{36} \mathrm{pH}$ SNEDDS F1 dapat diterima.

\section{Hasil Penetapan Kadar Nifedipin}

Prosedur penentuan kadar nifedipin dalam SNEDDS yaitu dilakukan validasi metode analisis dan dilanjutkan dengan penetapan kadar. Parameter validasi metode analisis yang diuji, antara lain linieritas, spesifitas, LOD, LOQ, akurasi, dan presisi. Hasil validasi metode penentuan kadar nifedipin tertera pada tabel 19. Larutan uji SNEDDS nifedipin F1 dengan konsentrasi uji 10 ppm diukur absorbansinya menggunakan spektrofotometer UVVis pada panjang gelombang 235,60 $\mathrm{nm}$ dengan menggunakan blanko metanol. Hasil penetapan kadar nifedipin tertera pada tabel 20. Persyaratan kadar nifedipin dalam sediaan kapsul mengandung nifedipin tidak kurang dari $90,0 \%$ dan tidak lebih dari $110,0 \%$ dari jumlah yang tertera pada etiket. ${ }^{21}$ Persyaratan kadar obat dalam SNEDDS tidak kurang dari $90 \%{ }^{22}$ Berdasarkan hasil yang diperoleh, kadar nifedipin dalam sediaan SNEDDS memenuhi persyaratan.

Tabel 19. Hasil Validasi Metode

\begin{tabular}{cll}
\hline Parameter & \multicolumn{1}{c}{ Persyaratan } & \multicolumn{1}{c}{ Hasil } \\
\hline Spesifitas & $\lambda_{\max }=235 \mathrm{~nm}^{17}$ & $\lambda_{\max }=235,60 \mathrm{~nm}$ \\
\hline Linearitas & $\mathrm{r}^{2}>0,998^{18}$ & $\begin{array}{l}\mathrm{y}=0,0561 \mathrm{x}+0,00778 \\
\mathrm{r}^{2}=0,99987\end{array}$ \\
\hline LOD & \multicolumn{1}{c}{-} & $0,95 \mu \mathrm{g} / \mathrm{ml}$ \\
\hline LOQ & - & $2,87 \mu \mathrm{g} / \mathrm{ml}$ \\
\hline Akurasi & $\%$ recovery $=95-$ & $\%$ recovery $=104,057 \pm 1,856$ \\
& $105 \%^{19}$ & $\%$ \\
\hline Presisi & RSD $<2 \%^{20}$ & $\mathrm{RSD}=1,783 \%$ \\
\hline
\end{tabular}

Tabel 20. Hasil Penetapan Kadar Nifedipin Replikasi Kadar Nifedipin

\begin{tabular}{cc}
\hline 1 & $10,16 \mathrm{mg} / \mathrm{g}$ \\
\hline 2 & $9,48 \mathrm{mg} / \mathrm{g}$ \\
\hline 3 & $9,93 \mathrm{mg} / \mathrm{g}$
\end{tabular}

Rata-rata $\quad 9,857 \pm 0,345 \mathrm{mg} / \mathrm{g}$

Sebelum pengujian kadar sediaan, dilakukan validasi metode analisis. Menurut Dibbern et al., panjang gelombang maksimum nifedipin jika dipreparasi menggunakan pelarut metanol adalah $235 \mathrm{~nm} .{ }^{17}$ Pada penelitian ini diperoleh panjang gelombang maksimum pada 235,6 nm sehingga panjang gelombang ini yang digunakan pada penetapan kadar. Kurva baku nifedipin dibuat dengan mengukur absorbansi 6 larutan standar dengan konsentrasi $1 \mathrm{ppm}, 5 \mathrm{ppm}, 10 \mathrm{ppm}, 20 \mathrm{ppm}, 40$ ppm, dan 60 ppm. Pada pembuatan kurva baku diperoleh nilai $\mathrm{y}=0,0561 \mathrm{x}+0,00778$ dengan nilai $\mathrm{r}^{2}=0,99987$. Nilai $\mathrm{r}^{2}$ lebih dari 0,998 menunjukkan bahwa kurva baku yang dibuat linier. ${ }^{18}$ Batas deteksi (LOD) dan batas kuantitasi (LOQ) yang diperoleh masing-masing sebesar $0,95 \mu \mathrm{g} / \mathrm{ml}$ dan $2,87 \mu \mathrm{g} / \mathrm{ml}$. Konsentrasi uji yang digunakan sebesar 10 ppm sehingga melebihi LOD dan LOQ. Pengujian akurasi dan presisi dilakukan dengan metode spiking atau penambahan obat dengan dosis tertentu ke dalam matriks obat. Persen recovery yang diperoleh adalah $104,057 \pm 1,856 \%$. Persen recovery yang didapatkan masuk rentang 95-105\% sehingga dapat dikatakan bahwa metode yang dilakukan akurat. Nilai RSD yang diperoleh adalah $1,738 \%$. Persyaratan RSD adalah kurang dari $2 \%$ sehingga nilai ini masuk dalam persyaratan yang menunjukkan bahwa metode yang dilakukan presisi.

Hasil uji kadar nifedipin dalam sediaan yaitu didapatkan kadar nifedipin sebesar 9,857 $\pm 0,345 \mathrm{mg} / \mathrm{g}$. Hasil yang diperoleh menunjukkan bahwa kadar obat lebih dari $90 \%$. Hal ini mengindikasikan bahwa dispersi obat dalam formula SNEDDS seragam..$^{22}$ Kadar nifedipin dalam formula SNEDDS juga memenuhi persyaratan yang ditetapkan dalam FI V, yaitu kapsul nifedipin mengandung nifedipin tidak kurang dari 90,0\% dan tidak lebih dari $110,0 \%$ dari jumlah yang tertera pada etiket. ${ }^{21}$ Kadar nifedipin dalam SNEDDS juga memenuhi persyaratan kadar obat dalam SNEDDS yaitu tidak kurang dari $90 \% .22$

\section{Daftar Pustaka}

1. Delacroix S., Chokka R. G., dan Worthley S. G. Hypertension: Pathophysiology and Treatment. Journal of Neurology \& Neurophysiology. 2014; 5 (6): 1-8.

2. World Health Organization. A Global Brief on Hypertension, WHO Press, Geneva. 2013.

3. Aronow W. S. Treatment of systemic hypertension. Am J Cardiovasc Dis. 2012; 2 (3): 160-170.

4. Sweetman S. C. Martindale: The Complete Drug Reference. Pharmaceutical Press, London. 2009; hal. 1350-1357.

5. U.S. Pharmacopeia. USP 30/The National Formulary, NF 25. U.S. Pharmacopeial Convention, Inc., Rockville. 2007; hal. 2752.

6. Gajendran J., Kramer J., Shahm V. P., Langguth P., Polli J., Mehta M., et al. Biowaiver Monographs for Immediate-Release Solid Oral Dosage Forms: Nifedipine. Journal of Pharmaceutical Sciences. 2015; 104: 3289-3298.

7. Kotta S., Khan A. W., Pramod K., Ansari S. H., Sharma, R. K., dan Ali, J. Exploring oral nanoemulsions for bioavailability enhancement of poorly water-soluble drugs. Expert Opinion on Drug Delivery. 2012; 9 (5): 585-598.

8. Chavda V. P. dan Shah D. A Review on Novel Emulsification Technique: A Nanoemulsion. Research and Reviews: Journal of Pharmacology and Toxicological Studies. 2017; 5 (1): 29-37.

9. Singh Y., Meher J. G., Raval K., Khan F. A., Chaurasia M., Jain N. K., dan Chourasia M. K. Nanoemulsion: Concepts, development and applications in drug delivery. Journal of Controlled Release. 2017; 252: 2849.

10. AboulFotouh K., Allam A. A., El-Badry M., El-Sayed A. M. Role of self-emulsifying drug delivery systems in optimizing the oral delivery of hydrophilic 
macromolecules and reducing interindividual variability. Colloids and Surfaces B: Biointerfaces. 2018; 167: 82-92.

11. Tanvi G., Sanjay C., Kishor S., Sachin G., dan Snehal H. A Review on Formulation Techniques of Solid Self Nanoemulsifying Drug Delivery System. Journal of Advanced Drug Delivery. 2016; 3 (3): 34-41.

12. Reddy M S. dan Sravanthi B. Formulation and In Vitro Characterization of Solid-self Nanoemulsifying Drug Delivery System of Atorvastatin Calcium. Asian Journal of Pharmaceutics. 2017; 11 (4): S991-S999.

13. Weerapol Y., Limmatvapirat S., Nunthanid J., dan Sriamornsak P. Self-Nanoemulsifying Drug Delivery System of Nifedipine: Impact of HydrophilicLipophilic Balance and Molecular Structure of Mixed Surfactants. American Association of Pharmaceutical Scientists Pharmaceutical Science Technology. 2014; 15 (2): 456-464.

14. Soni G. C. dan Prajapati S. K. Self Nano Emulsifying Drug Delivery System (SNEDDS): Development, Optimization And Characterization Of Pioglitazone Hydrochloride. International Journal of Pharma and Bio Sciences. 2017; 8 (4): 82-95.

15. Pratiwi L., Fudholi A., Martien R., Pramono, S. Selfnanoemulsifying Drug Delivery System (Snedds) for Topical Delivery of Mangosteen Peels (Garcinia Mangostana 1.,): Formulation Design and In vitro Studies. Journal of Young Pharmacists. 2017; 9 (3): 341-346.

16. Saritha D., Bose P. dan Nagaraju R. Formulation and Evaluation of Self-Nanoemulsifying Drug Delivery System of Naproxen. International Journal of Pharmaceutical Sciences and Nanothechnology. 2015; 8 (1): 2715-2722.

17. Dibbern H. W., Müller R. M., Wirbitzki E. UV and IR Spectra: Pharmaceutical Substances (UV and IR) and Pharmaceutical and Cosmetic Excipients (IR). Editio Cantor Verlag, Aulendorf. 2002.

18. Christian G. D., Dasgupta P. K., Schug K. A. Analytical Chemistry, Seventh Edition. John Wiley \& Sons, Inc., United States of America. 2014.

19. Harmita. Petunjuk Pelaksanaan Validasi Metode Dan Cara Perhitungannya. Majalah Ilmu Kefarmasian. 2004; 1 (3): 117-135.

20. Ermer J. dan Miller J. H. M. Method Validation in Pharmaceutical Analysis. WILEY-VCH Verlag GmbH \& Co. KGaA, Weinheim. 2005.

21. Departemen Kesehatan Republik Indonesia. Farmakope Indonesia Edisi V, Jakarta. 2015.

22. Nasr A., Gardouh A., dan Ghorab M. Novel Solid SelfNanoemulsifying Drug Delivery System (S-SNEDDS) for Oral Delivery of Olmesartan Medoxomil: Design, Formulation, Pharmacokinetic and Bioavailability Evaluation. Pharmaceutics. 2016; 8 (20): 1-29.

23. Wang L., Dong J., Chen J., Eastoe J., dan Li, X. Design and optimization of a new self-nanoemulsifying drug delivery system. Journal of Colloid and Interface Science. 2009; 330 (2): 443-448.
24. Azeem A., Rizwan M., Ahmad F. J., Iqbal Z., Khar R. K., Aqil M. A, dan Talegaonkar S. Nanoemulsion Components Screening and Selection : a Technical Note. American Association of Pharmaceutical Scientists Pharmaceutical Science Technology. 2009; 10 (1): 69-76.

25. Tran T. H., Guo Y., Song D., Bruno R. C., dan Lu X. Quercetin-Containing Self-Nanoemulsifying Drug Delivery System for Improving Oral Bioavailability. Journal of Pharmaceutical Sciences. 2014; 103: 840852.

26. Zeng L., Xin X., dan Zhang Y. Development and characterization of promising Cremophor EL-stabilized $\mathrm{o} / \mathrm{w}$ nanoemulsions containing short-chain alcohols as a cosurfactant. Royal Society of Chemistry Advances. 2017; 7: 19815-19827.

27. Jafari S. M. dan McClements D. J. Nanoemulsion: Formulation, Applications, and Characterization. Academic Press, London. 2018.

28. Mason T. G., Wilking J. N., Meleson K., Chang C. B., dan Graves S. M. Nanoemulsions: formation, structure, and physical properties. Journal of Physics: Condensed Matter. 2006; 18: R635-R666.

29. Patel J., Patel A., Raval M., dan Sheth N. Formulation and development of a self-nanoemulsifying drug delivery system of irbesartan. Journal of Advanced Pharmaceutical Technology \& Research. 2011; 2 (1): 916.

30. Lawrence M. J. dan Reee G. D. Microemulsion-based media as novel drug delivery systems. Advanced Drug Delivery Reviews. 2000; 45: 89-121.

31. Khan A. W., Kotta S., Ansari S. H., Sharma R. K., dan Ali J. Self-nanoemulsifying drug delivery system (SNEDDS) of the poorly water-soluble grapefruit flavonoid Naringenin: design, characterization, in vitro and in vivo evaluation. Drug Delivery. 2015; 22 (4): 552-561.

32. Nepal P. R., Han H. K., dan Choi H. K. Preparation and in vitro-in vivo evaluation of Witepsol® $\mathrm{H} 35$ based self-nanoemulsifying drug delivery systems (SNEDDS) of coenzyme Q10. European Journal of Pharmaceutical Sciences. 2010; 39: 224-232.

33. Zhang Y., Shang Z., Gao C., Du M., Xu S., Song H., dan Liu T. Nanoemulsion for Solubilization, Stabilization, and In Vitro Release of Pterostilbene for Oral Delivery. American Association of Pharmaceutical Scientists Pharmaceutical Science Technology. 2014; 15 (4): 1000-1008.

34. Saberi A. H., Fang Y., dan McClements D. J. Fabrication of vitamin E-enriched nanoemulsions: Factors affecting particle size using spontaneous emulsification. Journal of Colloid and Interface Science. 2013; 391: 95-102.

35. Pouton C. W. Formulation of self-emulsifying drug delivery systems. Advance Drug Delivery Reviews. 1997; 25: 47-58.

36. 3ones, David. FASTtrack: Pharmaceutics Dosage Form and Design. Pharmaceutical Press, London. 2018. 